Ким А. С., Довгополов Е. Ю.

A. S. Kim, E. Yu. Dovgopolov

ИНСТИТУЦИОНАЛЬНЫЕ АСПЕКТЫ ФОРМИРОВАНИЯ СИСТЕМЫ РАННЕГО ПРЕДУПРЕЖДЕНИЯ МЕЖЭТНИЧЕСКИХ КОНФЛИКТОВ НА РЕГИОНАЛЬНОМ И МУНИЦИПАЛЬНОМ УРОВНЯХ В ХАБАРОВСКОМ КРАЕ (НА ПРИМЕРЕ СТУДЕНЧЕСКОЙ МОЛОДЁЖИ)

\title{
INSTITUTIONAL ASPECTS OF THE FORMATION OF THE EARLY WARNING SYSTEM OF INTERETHNIC CONFLICTS AT THE REGIONAL AND MUNICIPAL LEVELS IN THE KHABAROVSK TERRITORY (IN THE CASE OF STUDENT YOUTH)
}

Ким Александр Сергеевич - доктор политических наук, профессор кафедры социально-гуманитарных наук Хабаровского государственного университета экономики и права, профессор кафедры социологии, политологии и регионоведения Тихоокеанского государственного университета (Россия, Хабаровск); 680035, г. Хабаровск, ул. Тихоокеанская, 134; ул. Тихоокеанская, 136; тел.: + 7 (924) 115-91-79. E-mail: stosorok2005@yandex.ru.

Mr. Alexander S. Kim - Dr. hab. of Political Sciences, Professor, Department of Social and Human Sciences, Khabarovsk State University of Economics and Law, Department of Sociology, Political Science and Regional Studies, Pacific State University (Russia, Khabarovsk); 680035, Khabarovsk, 134 Tikhookeanskaya str.; 136 Tikhookeanskaya str.; tel.: + 7 (924) 115-91-79. E-mail: stosorok2005@yandex.ru.

Довгополов Егор Юрьевич - кандидат юридических наук, доцент, юрист Центра исследования проблем российского права (Россия, Москва); 680035, г. Хабаровск, ул. Тихоокеанская, д. 140, общежитие № 1 ТОГУ, к. 503; тел.: + 7 (914) 547-33-78. E-mail: Degor@pochta.ru.

Mr. Yegor Yu. Dovgopolov - PHD in Law, Associate Professor, Lawyer, Center for Problems of Russian Law Research (Russia, Moscow); 680035, Khabarovsk, 140 Tikhookeanskaya str., dormitory No. 1 of Pacific State University, room 503; tel.: + 7 (914) 547-33-78. E-mail: Degor@pochta.ru.

Аннотация. В статье выявлены институциональные аспекты раннего предупреждения межэтнических конфликтов на примере студенческой молодёжи. Авторы определяют основное содержание этих аспектов как деятельность образовательных институтов по управлению социальными процессами в молодёжной среде. Обоснованы направления этой деятельности: 1) работа по формированию высокой культуры межнационального общения в студенческих коллективах; 2) разработка алгоритмов управления различными идейно-политическими трендами в студенческой среде с целью формирования общероссийского патриотического сознания. Указано, что раннее предупреждение межэтнических конфликтов в молодёжной среде должно быть составной частью деятельности по формированию общей регионально-муниципальной системы конфликтологического мониторинга и конфликтопредупреждения. Обоснованы факторы, затрудняющие формирование системы раннего предупреждения межэтнических конфликтов на региональном и муниципальном уровнях, определены пути решения этой проблемы.

Summary. The article reveals the institutional aspects of interethnic conflicts early warning in the case of student youth. The authors define the main content of these aspects as the activity of educational institutions in the management of social processes in the youth environment. The areas of this activity are substantiated: 1) formation of high culture of interethnic communication in student groups; 2) development of algorithms to manage various ideological and political trends in a student environment aimed at forming all-Russian patriotic consciousness. It is pointed out that early warning of interethnic conflicts in the youth environment should be an integral part of the formation of a common regional and municipal conflict monitoring system and conflict prevention. Factors that hamper the formation of an early warning system of interethnic conflicts at the regional and municipal levels are substantiated, and ways of solving have been determined.

Ключевые слова: «Стратегия государственной национальной политики Российской Федерации на период до 2025 года», институционализация, конфликтологическая превентивная деятельность в сфере этноконфессиональных отношений, система конфликтологического мониторинга и раннего предупреждения кон- 
Ким А. С., Довгополов Е. Ю.

ИНСТИТУЦИОНАЛЬНЫЕ АСПЕКТЫ ФОРМИРОВАНИЯ СИСТЕМЫ РАННЕГО ПРЕДУПРЕЖДЕНИЯ МЕЖЭТНИЧЕСКИХ КОНФЛИКТОВ НА РЕГИОНАЛЬНОМ И МУНИЦИПАЛЬНОМ УРОВНЯХ В ХАБАРОВСКОМ КРАЕ (НА ПРИМЕРЕ СТУДЕНЧЕСКОЙ МОЛОДЁЖИ)

фликтных ситуаций, студенческая молодёжь, образовательные организации, этнический национализм, патриотическое воспитание.

Key words: «Strategy of the state national policy of the Russian Federation for the period up to 2025», institutionalization, conflictology preventive activity in the sphere of ethnoconfessional relations, the system of conflict monitoring and early warning of conflict situations, student youth, educational organizations, ethnic nationalism, patriotic education.

\section{УДК 323.1}

Современные реалии социально-политического развития России свидетельствуют об острой необходимости формирования институтов и методики раннего предупреждения межэтнических и межконфессиональных конфликтов. Профилактика проявлений этнического национализма и патриотическое воспитание молодёжи, прежде всего учащейся, являются одними из важных условий конфликтологической превентивной деятельности в сфере этноконфессиональных отношений. Дело в том, что учащиеся образовательных организаций являются тем человеческим потенциалом, который в наибольшей степени подвержен разнообразным идейно-политическим воздействиям. Так, студенчество в этом плане наиболее подвержено влиянию сетевых структур, формирующихся в пространстве массовой коммуникации. Как свидетельствуют события на Украине, деструктивные силы в своих узкокорыстных целях проводят политическую мобилизацию молодёжи, заменяя истинный патриотизм радикальным национализмом. В этой связи представляется актуальным в научном и практическом отношении выявление институционально-политических аспектов формирования системы конфликтологического мониторинга и конфликтопредупреждения в сфере этноконфессиональных отношений, составной частью которой является образовательно-воспитательная превентивная деятельность образовательных организаций.

Первым направлением превентивной деятельности образовательных организаций является кропотливая работа по формированию высокой культуры межнационального общения в студенческих коллективах. С одной стороны, необходима интеграция студенческих групп на основе коллективных ценностей (образования, науки, студенческой субкультуры), а с другой - проведение работы, направленной на ознакомление с традициями, искусством и духовными ценностями народов России и бывшего СССР. Сфера досуга студенческой молодёжи должна быть наполнена мероприятиями интегрирующего характера, направленными на формирование единой студенческой «корпорации». Студенчество должно самоидентифицироваться как наиболее передовая часть молодёжи, от которой в значительной мере зависит продвижение страны по пути модернизации и демократического развития. Такая самооценка обусловит формирование в студенческой среде ценностных установок, которые соответствовали бы объективным общественным потребностям патриотического воспитания на основе толерантности и межнационального согласия. Целесообразно продумать формы и механизмы вовлечения студентов в интеграционную деятельность. Это во многом снимало бы вопросы негативного влияния националистических стереотипов и предрассудков. Из опыта СССР можно было бы заимствовать некоторые практики при условии их адаптации к современным реалиям. Речь идёт, например, о клубах весёлых и находчивых, студенческих строительных отрядах, ударных комсомольских стройках, интернациональных молодёжных коллективах, клубах интернациональной дружбы, днях героя-антифашиста.

Следующим направлением рассматриваемой деятельности является разработка алгоритмов управления различными идейно-политическими трендами в студенческой среде с целью формирования общероссийского патриотического сознания. Следует отметить, что такая кардинально новая проблема так и не начала эффективно решаться в течение последних двух десятилетий после распада СССР. Применительно к раннему предупреждению межэтнических конфликтов и патриотическому воспитанию молодёжи следует отметить, что современное российское государство так и не сформировало систему социально-политических ценностей, которые бы пришли на смену идеологии советского патриотизма. Здесь следует указать на две фундаментальные проблемы. Вопервых, это проблема формирования общероссийской идентичности, ценностных установок граж- 


\section{Учёные записки}

Комсомольского-на-Амуре государственного технического университета

данского патриотизма в условиях политического плюрализма, взаимодействия различных идейнополитических трендов. Во-вторых, речь идёт о проблеме формирования патриотического сознания применительно к современным реалиям России, которая является, в отличие от СССР, не интернациональным, а национальным государством (формирование российской нации).

$\mathrm{C}$ целью решения вышеперечисленных проблем необходим такой формат патриотического сознания молодёжи, который предполагал бы межнациональное согласие и сотрудничество как условие продвижения и укрепления патриотических ценностей. Более того, в содержание основных направлений превентивной деятельности образовательных организаций должны входить: 1) интерактивные мероприятия с участием представителей молодёжи различных политических ориентаций в формате свободной дискуссии; 2) сочетание различных идейно-политических тенденций в молодёжной среде с целью их интеграции в общегражданскую патриотическую платформу.

На сегодняшний день единственным документом, который в известной степени определяет мировоззренческую направленность деятельности образовательных институтов по гармонизации межнациональных отношений и патриотическому воспитанию, является «Стратегия государственной национальной политики Российской Федерации до 2025 года», введённая в действие Указом Президента Российской Федерации от 19 декабря 2012 г. № 1666 [3]. Она была актуализирована 22 октября 2013 г. на заседании Совета по межнациональным отношениям при Президенте Российской Федерации [4]. На этом заседании В. В. Путиным была высказана необходимость создания на единой методологической основе региональных центров мониторинга межэтнических отношений, оценки рисков и предупреждения конфликтных ситуаций [4].

Исходя из вышеизложенного, представляется, что деятельность образовательных институтов по раннему предупреждению межэтнических конфликтов должна быть составной частью более широкой системы конфликтологического мониторинга и конфликтопредупреждения в сфере этноконфессиональных отношений. На наш взгляд, обстоятельствами, затрудняющими процесс институционализации формирования такой системы превентивной деятельности, являются следующие факторы ментального характера:

- во-первых, существует проблема неподготовленности управленческих и социализирующих институтов к выполнению требований сегодняшнего дня (за редким исключением, основная масса региональных государственных и муниципальных служащих, работающих в сфере реализации «Стратегии государственной национальной политики Российской Федерации на период до 2025 года», педагогический и профессорско-преподавательский состав образовательных организаций не имеют этнополитической компетентности и не владеют необходимыми знаниями и навыками, необходимыми для специализированной превентивной деятельности в области этноконфессиональных отношений);

- во-вторых, в общественном и научном дискурсах весьма сильно проявляются установки, связанные с недопониманием сущности и роли «регулярной профилактики, разработки форм и способов поддержания позитивных (консенсусных) бесконфликтных межэтнических отношений» $[2,17]$ (в основном признаётся необходимость регулирования и разрешения уже сформировавшихся конфликтов, которые в большинстве случаев рассматриваются «как “пожаротушение”, то есть непосредственное воздействие на конфликт с целью его немедленного прекращения» [2, 16-17]);

- в-третьих, существует стереотипное убеждение, что предупреждение радикального национализма и этнического экстремизма в молодёжной среде как важнейший фактор формирования патриотического сознания - это исключительно функция правоохранительных органов (неудивительно, что при этом происходит непонимание места и роли учебно-воспитательной и научнообразовательной деятельности в образовательных организациях по раннему и глубокому предупреждению националистических проявлений на мировоззренческом уровне).

Вышеперечисленные факторы обусловливают недостаточную институционализацию деятельности на региональном и муниципальном уровнях по формированию системы раннего предупреждения межэтнических конфликтов, вследствие чего отдельные разрозненные усилия не получают должной административно-ресурсной и финансовой поддержки и не трансформируются 
Ким А. С., Довгополов Е. Ю.

ИНСТИТУЦИОНАЛЬНЫЕ АСПЕКТЫ ФОРМИРОВАНИЯ СИСТЕМЫ РАННЕГО ПРЕДУПРЕЖДЕНИЯ МЕЖЭТНИЧЕСКИХ КОНФЛИКТОВ НА РЕГИОНАЛЬНОМ И МУНИЦИПАЛЬНОМ УРОВНЯХ В ХАБАРОВСКОМ КРАЕ (НА ПРИМЕРЕ СТУДЕНЧЕСКОЙ МОЛОДЁЖИ)

в скоординированные проекты превентивной деятельности. Во многом это вызвано тем, что в настоящее время в Хабаровском крае отсутствуют региональные законодательные нормы, которые регламентировали бы специализированную деятельность органов государственной власти по раннему предупреждению межэтнических и межконфессиональных конфликтов.

Однако при всей сложности ситуации вселяет надежду решение Правительства Хабаровского края по учреждению автономной некоммерческой организации (АНО) «Краевой научнопрактический центр по мониторингу этноконфессиональных отношений и раннему предупреждению конфликтных ситуаций» [1], начавшей свою деятельность в 2016 г. Данная структура является институтом общественно-государственного участия в формировании единой системы конфликтологического мониторинга этноконфессиональных отношений и раннего предупреждения конфликтных ситуаций на региональном и муниципальном уровнях в Хабаровском крае.

Основной целью деятельности АНО является предоставление услуг в сфере государственной национальной политики, направленных на обеспечение межнационального мира, гармонизацию межнациональных (межэтнических) отношений и раннее предупреждение конфликтных ситуаций на территории Хабаровского края. За период с конца 2016 г. по настоящее время данной организацией было осуществлено несколько конфликтологических мониторингов этнополитических и этноконфессиональных отношений в крае, охвативших в общей сложности более 15 тысяч человек. Кроме того, были организованы и проведены интерактивные мероприятия, направленные на гармонизацию этноконфессиональных отношений, в форме научно-образовательных конференций, обучающих и методических семинаров, мастер-классов. Были разработаны методические рекомендации по раннему предупреждению конфликтных ситуаций в сфере этноконфессиональных отношений в рамках реализации «Стратегии государственной национальной политики Российской Федерации на период до 2025 года» на региональном и муниципальном уровнях, в том числе предназначенные для работы с учащейся молодёжью. Была оказана консультационная и методическая поддержка государственным, коммерческим и некоммерческим организациям, выдвигающим инициативы и реализующим проекты в сфере гармонизации этноконфессиональных отношений. Осуществлялась организация и популяризация этноконфликтологической превентивной деятельности в крае посредством создания и продвижения на интерактивных мероприятиях и в социальных сетях текстовой и видеоинформации по проблематике этноконфессиональных отношений.

Вместе с тем следует констатировать, что создание вышеуказанной АНО и успешные результаты её деятельности являются только первым шагом в сложном процессе институционализации формирования системы конфликтопредупреждения и конфликторазрешения в сфере этноконфессиональных отношений на региональном и муниципальном уровнях. Для того, чтобы данная система была в общем и целом создана, необходимы решения следующих задач:

1) формирование методологии и методики конфликтопредупреждения и конфликторазрешения в сфере межнациональных отношений в тесном взаимодействии с экспертным сообществом;

2) внедрение конфликтологической методологии и методики в различные целевые программы национальной политики;

3) интеграция на региональном и муниципальном уровнях институциональных блоков превентивной деятельности в единую систему конфликтологического мониторинга межнациональных отношений и раннего предупреждения конфликтных ситуаций.

К институциональным блокам превентивной деятельности относятся следующие системнофункциональные компоненты:

- 1-й блок - федеральные и региональные органы государственной власти, органы местного самоуправления. Основная функция данного блока - организационно-распорядительное, административно-политическое и программно-целевое обеспечение реализации «Стратегии государственной национальной политики Российской Федерации на период до 2025 года»;

- 2-й блок - некоммерческие организации и другие общественные объединения. Основная функция этого блока - этнокультурное, культурно-эстетическое, социально-защитное и обще- 
ственно-гражданское сопровождение национальной политики (установление гражданского мира и межнационального согласия);

- 3-й блок - правоохранительный (институты прокуратуры, органов внутренних дел, Федеральной службы безопасности). Основная функция этого блока - правоохранительное и оперативно-силовое обеспечение национальной политики, то есть правоохранительная регуляция межнациональных отношений на основе выявления, предупреждения и пресечения противоправных проявлений, связанных с элементами этнорелигиозной ксенофобии, дискриминации по национальному и религиозному признакам, этнического и религиозного экстремизма и радикального национализма;

- 4-ый блок - научно-образовательные и воспитательные организации и учреждения. Основная функция этого блока - превентивная деятельность, предполагающая раннюю профилактику путём минимизации предпосылок восприятия экстремистской и радикальнонационалистической идеологий посредством научно-образовательной и социальновоспитательной работы.

Практическая реализация разрешения рассматриваемой проблемы состоит в формировании институтов инфраструктурной поддержки деятельности по раннему предупреждению конфликтных ситуаций в сфере этноконфессиональных отношений. Речь идёт о создании ресурсных центров, которые занимались бы информационным, консалтинговым, научно-исследовательским и образовательным ресурсным обеспечением деятельности по выработке практических навыков по формированию высокой культуры межнационального общения; информационно-аналитическому обеспечению этнокультурного развития и межнационального взаимодействия; методологии и методике раннего предупреждения конфликтных ситуаций в сфере межнациональных отношений, профилактике этнического экстремизма.

\section{ЛИТЕРАТУРА}

1. Итоговая резолюция Дальневосточного гражданского форума от 15 ноября 2015 г.: направлена врио начальника департамента по реализации общественных проектов Аппарата Полномочного представителя Президента Российской Федерации в Дальневосточном федеральном округе А. И. Веденяпиной, заместителю Председателя Правительства Хабаровского края, руководителю Аппарата Губернатора и Правительства края А. Н. Мкртычеву письмом от 29 декабря 2015 г. № А56-5138: п. 9 // Официальный сайт Общественной палаты Хабаровского края [Электронный ресурс]. - Режим доступа: http://www.opkhv.ru/civilforum 27/2015/materials/1597 (дата обращения: 10.04.2018).

2. Ким, А. С. Этнополитическая конфликтология современных диаспор: методология, теория, регионалистика: моногр. / А. С. Ким. - Хабаровск: Изд-во ТОГУ, 2011. - 330 с.

3. О «Стратегии государственной национальной политики Российской Федерации на период до 2025 года»:

Указ Президента Российской Федерации от 19 декабря 2012 г. № 1666 // Собрание законодательства Российской Федерации. - 2012. - № 52. - Ст. 7477.

4. Стенографический отчёт о заседании Совета по межнациональным отношениям при Президенте Российской Федерации 22 октября 2013 г. [Электронный ресурс]. - Режим доступа: http://state.kremlin.ru/council/28/ news/19475 (дата обращения: 10.04.2018). 